\title{
The Current State of the Tourist Market in Ukraine: Assessment and Prospects for Development
}

\author{
Bulgaru Natalia \\ natalia.bulgaru@ugal.ro \\ Susanu Irina \\ irina.susanu@,ugal.ro \\ Cristache Nicoleta \\ nicoleta.cristache@ugal.ro \\ Colan Aura \\ aura.colan@,ugal.ro \\ Dunarea de Jos University of Galati, Romania \\ Coroban Laurentiu \\ dorucoroban@yahoo.com \\ Western University of Timisoara, Romania
}

\begin{abstract}
The article briefly examines the changes in international tourist flows and the dynamics of international tourist revenues in the period 1996-2017; 2012-2018. It was made the diagnosis of flows by tourist regions of the world, and the tourism role trend has been established both locally and internationally. This trend was also found in Ukraine, based on the analysis of the tourist flows, a thorough diagnosis of the main indicators of the activity of entities in tourism: number of tourists served by the subjects of tourist activity, and the incomes of the enterprises of the tourist on the categories of legal and natural persons. It shows the importance of obtaining income from the provision of tourism services and their impact both on the activity of tourism enterprises and on the economy of the state. There is a close relationship between the level of income of the consumer and the level of income of the tourist enterprise. The analysis supported the elaboration of forecasts on revenues from tourism services in three development scenarios: pessimistic, realistic and optimistic.
\end{abstract}

Keywords: tourism; tourist market; evaluation; tourist flows; income of the tourist enterprise.

\section{Introduction}

Ukraine has great potential and almost all resources: natural thermal waters, hydropower, medical mud, mixed coniferous forests and coastal coasts. The development of tourism is impossible without normal interregional competition, that is, the progressive level of development of each tourist region in Ukraine depends on its ability to realize the existing tourist potential. Also it is important the development of domestic and foreign tourism, which could make a significant contribution to socio-economic development, affecting the income of local and state budgets, business development in tourism and related sectors.

The market of tourist services is considered as a stable one and that, therefore, in consideration of the latest trends in the market of tourist services in Ukraine, in particular, using economic instruments and calculus, is particularly important.

\section{Problem Statement}

It is to analyze the current state of the tourist market of Ukraine and to forecast revenues from the provision of tourist services as a key indicator of the development of tourism in the country. 


\section{Analysis of recent research and publications}

The foundations of Tourism Development were laid and developed by domestic scientists such as Lubitseva O., Kifiak V., Sokol T., Malskaya M., Khudo V., Tsybukh V., Dyadechko L. and others. These scientists have made a significant contribution to the development of the tourism industry: the study of the foundations of the theoretical definition of the laws, and the laws of the development of tourism, and the creation of effective mechanisms for the functioning of the tourism sector, the research and development of the resource potential of Ukraine, etc. The characteristics of the development of tourism in Ukraine are dedicated to the work of scholars such as Kovalchuk, S., Kosar N. Kuzio, N., Frolova, G., Pestushko V.

\section{Research Questions}

Despite the large number of studies, the problems of assessing the state of tourism, the connection between the components of the tourist services market and the prediction of development indicators, wasn't given enough attention. The market of tourist services is considered to be only static, and, therefore, in consideration of the latest trends in the market of tourist services in Ukraine, in particular, through the use of economic instruments and calculus, is particularly important.

\section{Presentation of the main research material}

The tourist market is considered rather flexible, because it responds quickly to the changes in tourism supply and demand and also responds acutely to changes in the environment (political, economic, social factors). Tourism is one of the most important sectors of the Ukrainian economy, providing not only revenue, but also to the creation of jobs, the development of a positive image of the state, increase of competitiveness of the national tourism. Therefore, it has a strong interest for the Ukrainian economy, however, the share of the income from tourism does not reach 1\% of GDP, while in countries where the tourist industry is well developed, it can generate up to 10 per cent of the country's GDP ${ }^{46}$.

Global trends in tourism development highlight the growth of its role both locally and in the world. International tourist flows were characterized in the period 1996-2017, mainly in addition to 2009, positive exchanges (Fig1)

Fig. 1. Dynamics of changes in international tourist flows, $\%$

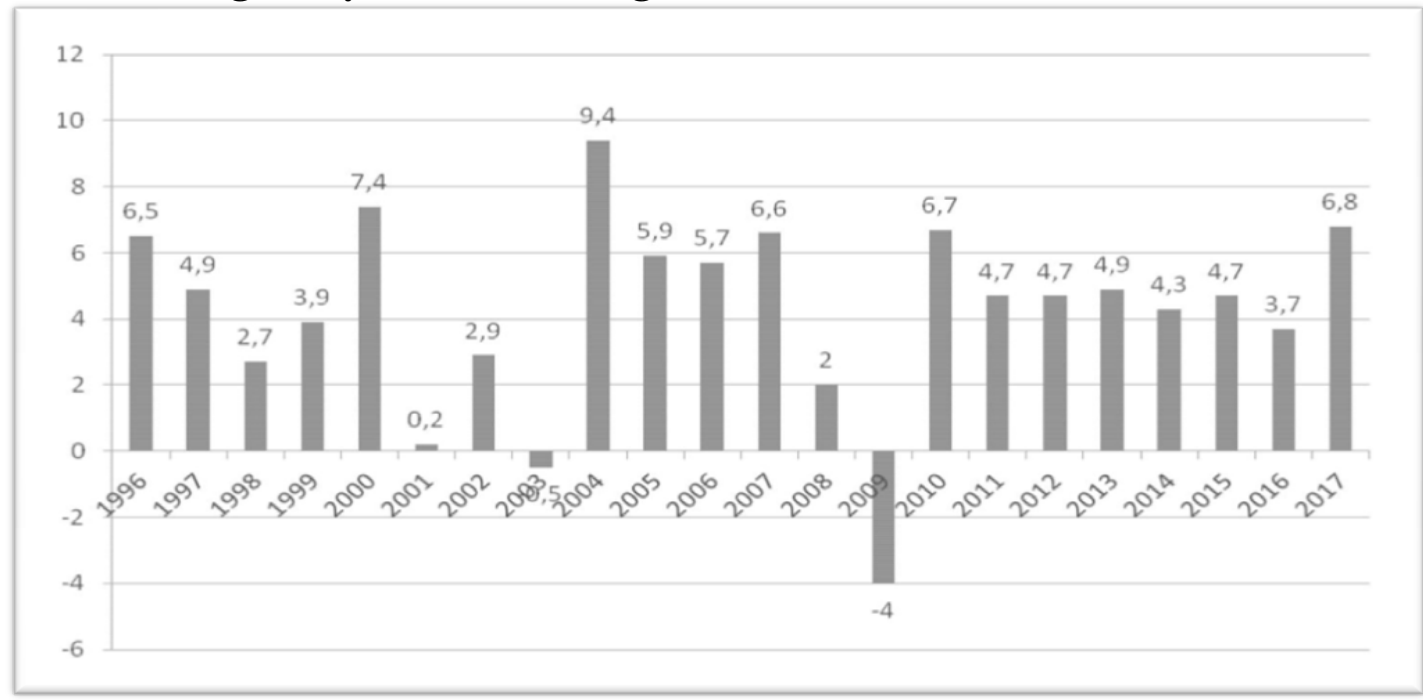

Source:The official site of http:/ / mkt.unwto.org/barometer United Nations World Tourism Organization (2018), "Statistics", available at: http:/ / www2.unwto.org

${ }^{46}$ The official site of United Nations World TourismOrganizationBarometr (2018), "World

TourismOrganizationBarometr", available at: http://mkt.un wto.org/barometer (Accessed 25 martie 2019) 
Thus, studying the dynamics of processes in tourist flows in the period 1995-2017, it is worth emphasizing that 2004 was characterized as a boom period, reaching a maximum growth of $9.4 \%$ compared to 2003 .

Table 1.Dynamics of changes in tourist flows, $\%$

\begin{tabular}{|l|l|l|l|}
\hline \multicolumn{1}{|c|}{ Geographical region } & \multicolumn{2}{|c|}{2017 growth } & \multicolumn{1}{c|}{$\begin{array}{c}\text { Growth 1 part of } \\
2018\end{array}$} \\
\hline & Mln.pers & $\%$ & $\%$ \\
\hline European Region & 671 & 8,4 & 6,8 \\
\hline Asia-Pacific Region & 324 & 5,6 & 7,8 \\
\hline American Region & 207 & 3,3 & 3,0 \\
\hline African Region & 62 & 9,0 & 5,6 \\
\hline Eastern Region & 58 & 4,6 & 4,5 \\
\hline
\end{tabular}

In relation to the same period the previous period

Source:The official site of http:/ / mkt.unwto.org/barometer United Nations World Tourism Organization (2018), "Statistics", available at: http:/ / wmw2.unwto.org/

Analyzing the world tourist flows, it should be noted that in 2017 there was a faster growth than in 2016, especially during this period, the volume of tourists increased by $6.8 \%$. In addition, the leaders present are France, Spain and the United States. At the same time, taking into account changes in the environment and trends in world economies, the forecast for 2018 shows a slight reduction in this indicator from 4 to $5 \%$, thereby reducing $1.8-2 \%$ of the number of tourists.

According to the World Tourism Organization UNWTO, Ukraine's share in tourist flows in Europe is about $4 \%$ and about $1 \%$ - in European tourism revenues. ${ }^{47}$

Tourism is an investment for the country. Thus, according to the U.S. Patent News and World Report ${ }^{48}$, the leading positions in the state's contribution to the development of tourism in the country are: Germany, Japan, the U.S., Britain, Switzerland. For example, Cyprus invests 20 million euros in promotion and receives $\$ 2$ billion, Georgia uses a budget of about $\$ 18$ million.

After assessing the dynamics of world tourist flows, we will analyze this indicator in Ukraine (Figure 2).

Fig. 2. Dynamics of tourist flows in Ukraine, people

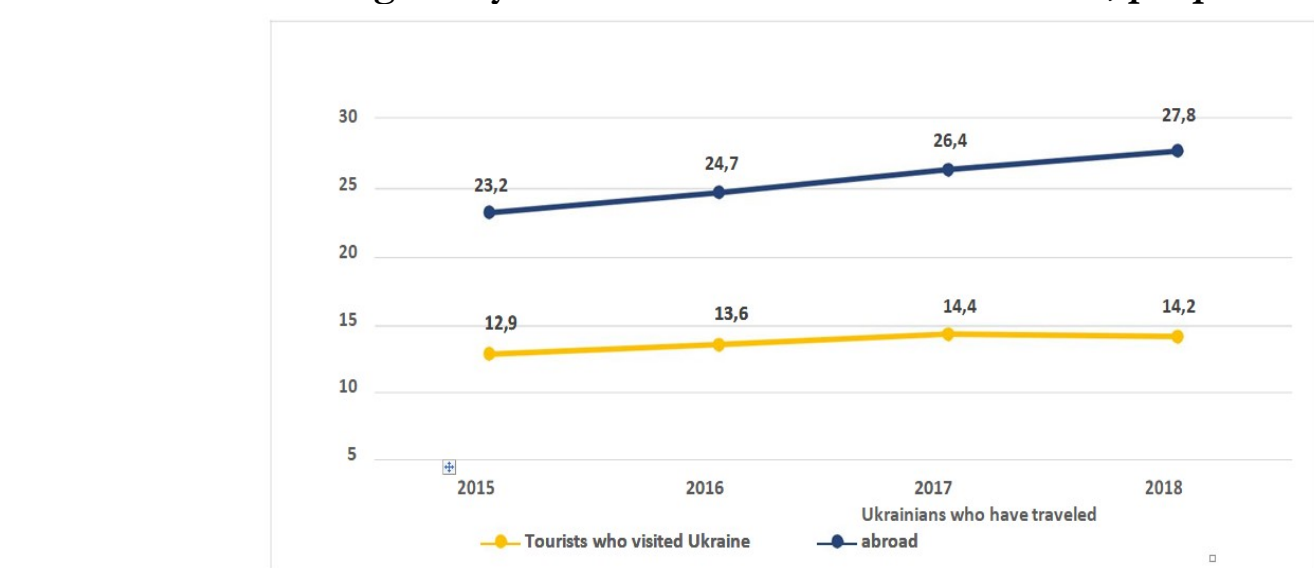

Source:built on data: http:/ / wmw.me.gov.ua/Documents/List?lang=uk-UA\&id=be44a1 a 7-69b3-4a77a86a-447499abcdd6 Eotag = Analitikaeois Special=true

\footnotetext{
${ }^{47}$ UNW'TO [electronic source]. - Access mode: http://www2.unwto.org/

${ }^{48}$ Entrepreneurship[electronic source]- Access mode: https://www.usnews.com/news/best-

countries/entrepreneurship-rankings
} 
According to the data obtained, it can be concluded that in the period under investigation (2015-2018) the dynamics of the number of foreign citizens who visited Ukraine is lower than Ukrainian citizens traveling abroad. Since 2015, the number of people wishing to visit Ukraine reflects positive developments, increasing the flow of foreign tourists. This is due to the extremely difficult events for Ukraine in 2013-2014. But if we estimate the dynamics of foreign tourist flows, then the number of foreign citizens who visited Ukraine in 2018 compared to 2015 increased by $3 \%$. Summing up the dynamics of tourist flows in the chosen period, compared to 2015 , the number of citizens traveling abroad increased by $7.8 \%$, which indicates a steady increase in demand, despite the economic situation in Ukraine. When analyzing the tourist flow in the period 2015-2018, there should be an increasing trend, although by 2018 the indicator of the incoming tourism remained at the level of 2017.

The main countries that the Ukrainians chose to leave (according to ${ }^{49}$ ) in 2018 were as follows (Figure 3).

\section{Fig. 3. Countries where Ukrainians most often traveled abroad}

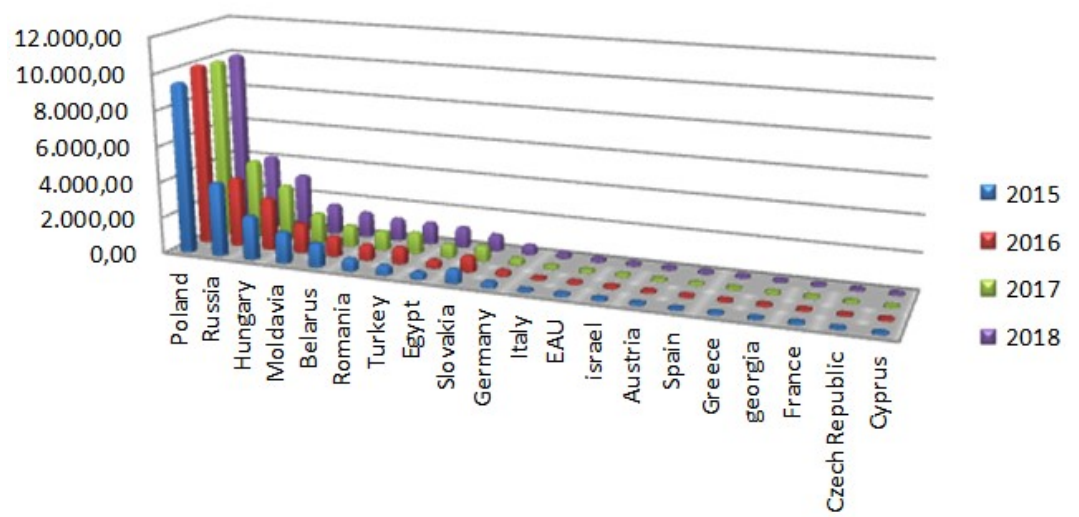

Source: built on data: http:// wmw.me.gov.ua/Documents/List?lang=uk-UA\&id=be44a1a7-69b3-4a77a86a-447499abcdd6 étag $=$ Analitikadois Special=true

Thus, Poland takes first place in the preferences of Ukrainians to travel abroad, with $98 \%$ of tourists focusing on a private trip, which was also characteristic of other countries to visit, followed by Russia and Hungary.

Fig. 4. Number of people of tourist activities in Ukraine, units

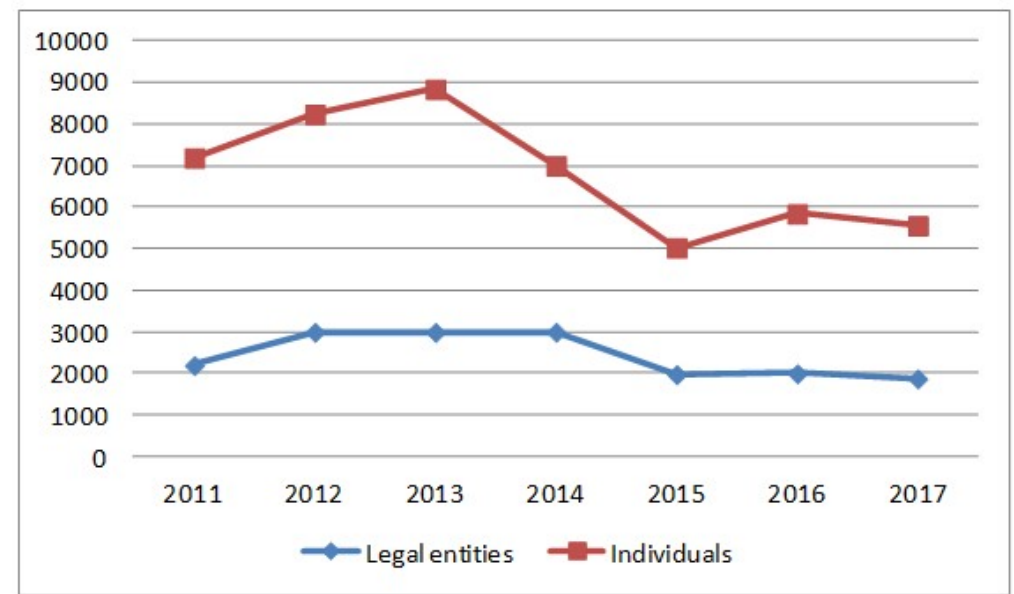

Source: built on data The official site of http:/ / mkt.unwto.org/ barometerState Statistics Service of Ukraine (2018), available at: http:// www.ukrstat.gov.ua

${ }^{494}$ Administration of the State Border Guard service of Ukraine [electronic resources]. - Access mode: https://dpsu.gov.ua/ 
The structure of the types of tourist activity networks is the most numerous category of travel agents whose share is more than $80 \%$ of the subjects. The peak of tourist activity occurred in 2012 and 2013 can be explained by the championship Euro-2012, after which there was a sharp decline in both the number of people and low income. And, in 2017 the number of legal entities decreased by $6 \%$.

Analyzing the number of tourists served by people of tourist activity during the year, there were more than 2.7 million people (by $8 \%$ more than 2017), foreign tourists - almost 40 thousand people (in 2017, respectively, it was 35 thousand). For the majority of tourists (85\%), the main purpose of the trip was Recreation. The income from the provision of tourist services by business entities is present in Fig.5.

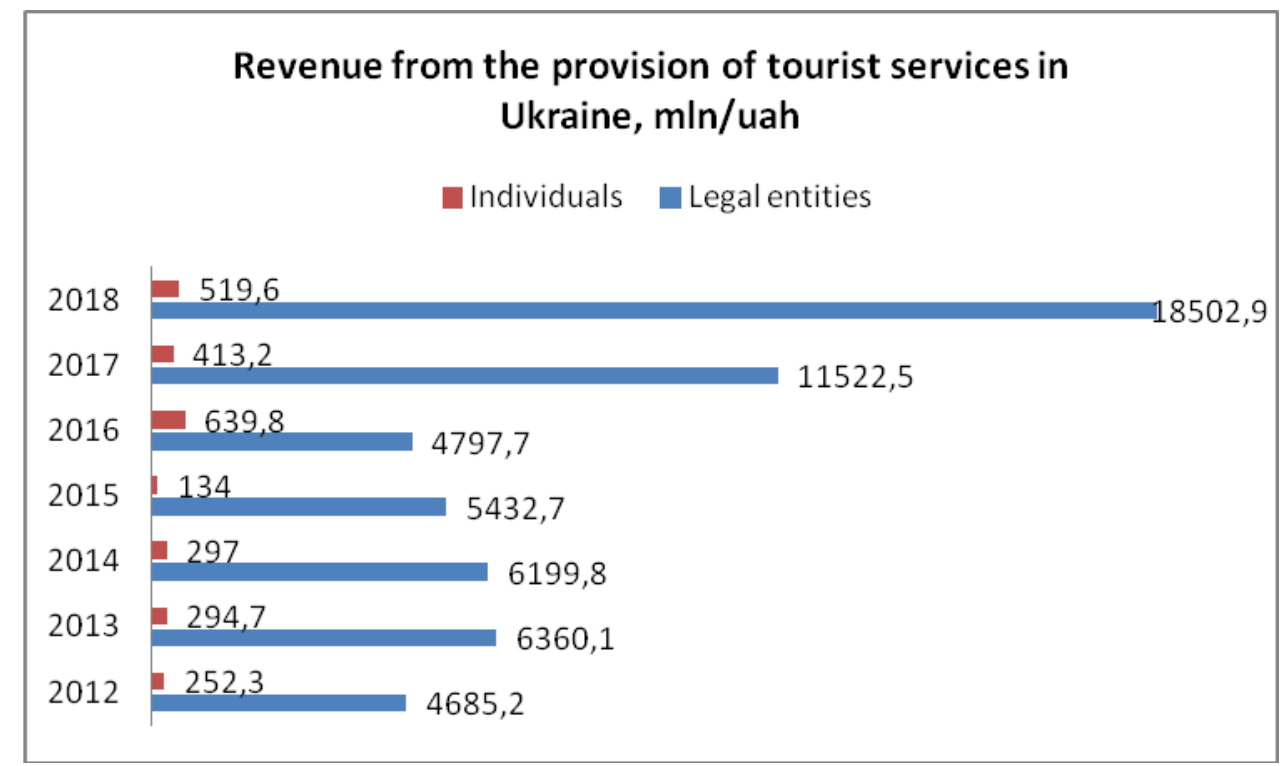

Source:built on data The official site of http:/ / mkt.unwto.org/barometerState Statistics Service of Ukraine (2018), available at: http:/ / wmw.ukrstat.gov.ua

Analyzing the data in Fig.5 it should be noted that, despite certain reduction in the number of tourism-related activities, in 2018, there has been a significant increase in the income of the legal entities that provide tourism services (this category includes tour operators, travel agents, and the entities that carry out activities of sight-seeing) more than $60 \%$ compared to the end of 2017. Also characterized by positive changes and personal income (travel agents and entities carrying out excursion activities), which increased by more than $25 \%$ compared to 2017 year.

At the same time, the increase in revenues from the provision of tourist services during the investigated period is associated with an increase in both the cost of tourist services and the increase in the number of vouchers sold (Statistics Service of Ukraine).

Table 2Assessment of tour operators by number of tourists served

\begin{tabular}{|c|l|c|}
\hline Place & Tour Operator & $\begin{array}{c}\text { Number of tourists who used the services } \\
\text { tour operator, thousands of people }\end{array}$ \\
\hline 1 & «oin UP!» & 500 \\
\hline 2 & «Anex Tour» & 374 \\
\hline 3 & «TG & 300 \\
\hline 4 & «Coral Travel» & 170 \\
\hline 5 & «PegasTouristik» & 130 \\
\hline 6 & «TEZ TOUR» & 120 \\
\hline 7 & «TUI Ukraine» & 100 \\
\hline
\end{tabular}




\begin{tabular}{|l|l|l|}
\hline 8 & «Chord Tour» & 77 \\
\hline 9 & «Mouzenidis Travel» & 54 \\
\hline 10 & «Fairye» & 50 \\
\hline
\end{tabular}

Source:Rating of Ukrainian tour operators (2016), available at: http:/ /joinuplviv.com/ reitynh-turoperatorivukrainy-2016

Table 3. Rating of tour operators by reviews of tourists

\begin{tabular}{|c|l|c|}
\hline Place & Tour Operator & Number of positive reviews \\
\hline 1 & «Chord Tour» & 5124 \\
\hline 2 & «TPG» & 5059 \\
\hline 3 & «Fairye» & 5008 \\
\hline 4 & «Alf» & 3494 \\
\hline 5 & «TEZ TOUR» & 2550 \\
\hline 6 & «Gamal» & 2055 \\
\hline 7 & «Mouzenidis Travel» & 2030 \\
\hline 8 & «PegasTouristik» & 2010 \\
\hline 9 & «Join UP!» & 1734 \\
\hline 10 & «TUI Ukraine» & 1679 \\
\hline
\end{tabular}

Source:The official site of http:/ / mkt.unwto.org/barometer Ukrainian marketing group. Available at: bttp:/ / www.umg.ua

It is also advisable to analyze the rating of tour operators in the most popular destinations - Turkey and Egypt among Ukrainian tourists in 2017. Ukraine took 7th place among the leaders in terms of the number of tourists who visited Turkey in $2017^{50}$. In the specified period, this recreation region was chosen by 1,212,644 tourists, $23 \%$ more than in the same period in 2016 .

Fig. 6. Purpose of visiting tourists in Kiev 2018

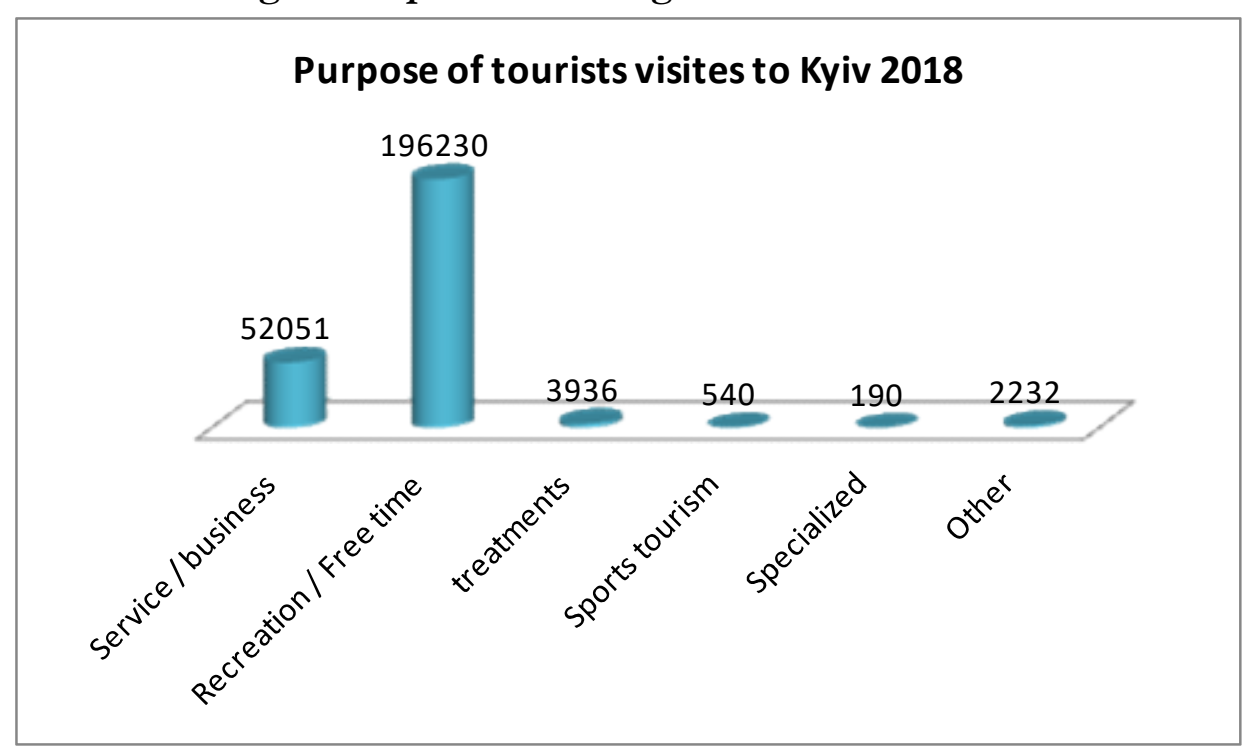

Source: built on data The official site of http:/ / mkt.unwto.org/barometer the Main Department of Statistics in Kyiv (2018), available at: bttp: / / wmw.kiev.ukrstat.gov.ua

According to the Department of Tourism and Promotion ${ }^{51}, 2017$ became the most effective in the context of the implementation of the target program and joint projects with

\footnotetext{
${ }^{50}$ Rating of Ukrainian tour operators (2017), available at: http://www.turprofi.com.ua/rejtingi/2046-letnie-rejtingituroperatorov-po-turtsii-2017
} 
business representatives in the field of international relations - more than 50 different events took place to create the tourist attractiveness of Kiev and increase the tourist flow. However, despite the development of tourism in certain cities, the tourism sector, unfortunately, compared with global trends, does not reach the desired level. Lack of places of attraction, lack of infrastructure, lack of logistics and, therefore, poor quality of services do not contribute to the development of tourism in Ukraine.

The low level of capacity utilisation of Ukraine's tourism potential is also confirmed by the insignificant contribution of the tourism sector to GDP (figure 7)

Figure 7 changing the share of revenues from tourism services in Ukrainian GDP

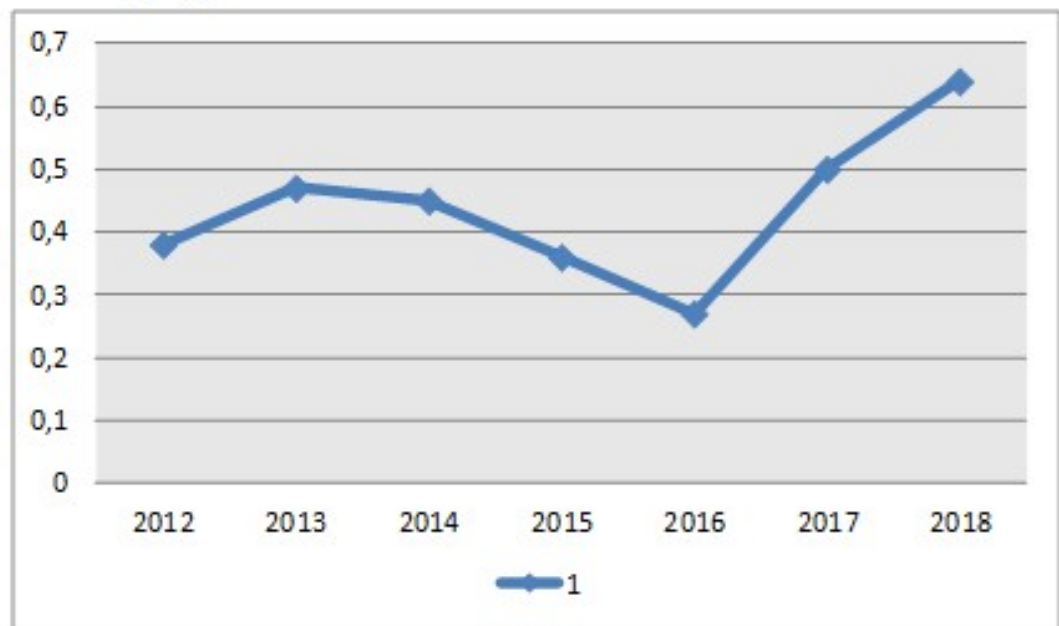

Source: built on data The official site of bttp:/ / mkt.unwto.org/barometer the Main Department of Statistics in Kyiv (2018), available at: http:/ / wmw.kiev.ukrstat.gov.ual

If we compare the share of tourism in Ukraine'S GDP in 2018, it will reach $0.64 \%$, while the world practice shows $6-10 \%$. This indicates that the level of development of tourism in Ukraine is very low. At the same time, the development of tourism in the next two years will depend more on environmental factors that, although indirectly influence, but its impact is extremely large. What scenario the tourism services market will develop, will depend on how each entity will conduct its activities.

\section{Results}

The income from the provision of tourism services has been selected as a key indicator of the development of the tourism industry in the country, taking into account the current exchange rate, the stage of economic development, the tax burden and the rate of inflation. Based on open information and using special provisions in MS Excel, we forecast scenarios for tourism development in Ukraine in three ways: pessimistic, realistic and optimistic (Table 4).

Table 4Forecasts of revenues from the provision of tourist services in Ukraine, $\mathrm{mln}$ / uah

\begin{tabular}{|r|r|r|r|}
\hline & Pessimistic & Realistic & \multicolumn{1}{c|}{ Optimistic } \\
\hline 2018 & 21366,08 & 21685,65 & 23850,5 \\
\hline 2019 & 21937,29 & 22447,95 & 27250,4 \\
\hline 2020 & 21613,81 & 22849,41 & 32002,5 \\
\hline \multicolumn{4}{|c}{ Source: calculated by the author } \\
\hline
\end{tabular}

${ }^{6}$ The official site of http://mkt.unwto.org/barometer State Administration of Kyiv (2018), available at: https://kyivcity.gov.ua/ 
Consequently, the forecast data obtained during the study indicates that 2018, under any development scenario will, show an increase in revenues from tourism services compared to 2017. At the same time, the development of tourism in the next two years will depend more on environmental factors that, although indirectly influence, but its impact is extremely large. What scenario the tourism services market will develop will depend on how each entity will conduct its activities.

\section{Conclusions}

Analyzing the dynamics of the development of the Ukrainian tourist services market in the period 2012-2018, it can be concluded that tourism is a sphere that brings not only income, but also a great potential for development. With considerable natural resources, and a good geographical location of the country, a large number of popular tourist attractions, with highly qualified staff and overcoming the problems of infrastructure and investment, the tourism sector can develop in a best-case scenario, thereby enhancing not only the effectiveness but also the results of the related fields. However, neglecting the objects of tourist heritage, the misuse of the natural resources, the lack of investment in the development of not only infrastructure, but also tourism in general, the immigration personnel in foreign countries may become a key factor in the choice of the ways of negative development. Therefore, when assessing the real situation on the market of tourist services in Ukraine, it should be noted that tourism is beginning to come to life only from the point of view of the economy, and - most important- the confidence of not only foreign tourists, but even more of to the citizens of Ukraine, proves the positive changes, the economy isn't going to be able to develop the tourism industry in a best-case scenario, which will be the subject of future research.

\section{References}

1. Liubitseva, O.O. (2002), Rynokturystychnykhposluh (heoprostoroviaspekty) [Market of tourist services (geospatial aspects)], Alterpres, Kyiv, Ukraine.

2. Kifyak, V.F. (2003), Orbanizatsiiaturystychnoidiial'nosti v Ukraini [Organization of tourism activity in Ukraine], Books XXI, Chernivtsi, Ukraine.

3. Sokol, T.G. (2006), Osnovyturyzmoznavstva :navchal'nyjposibnyk [Fundamentals of Tourism Studies: textbook], Slavic House, Kyiv, Ukraine.

4. Malskaya, M.P., Kbudo, V.V. and Cibuh, V.I. (2004), Osnoryturystychnohobiznesu: navchal'nyjposibnyke[ Fundamentals of Tourism Business: textbook], Center for Educational Literature, Kyiv, Ukraine.

5. Diadechko, L. P. (2007), Ekonomikaturystychnobobiznesu [Economy of tourism business], Center for Educational Literature, Kyiv, Ukraine.

6. Kovalchuk, S.V. and Mykohyshina, V.V. (2011), "The concept of the tourist market and the peculiarities of its functioning", Bulletin of the Khmelnitsky National University, Series: Economics, vol. 6, pp.60-65.

7. Kosar, N. and Kuzio, N. (2016), "Research on the de velopment of tourism in a crisis", Actual problems of theeconomy, vol. 2 (176), pp. 115-125.

8. Frolova, G.I. and Frolova, V.Yu. (2014), "Organizational fundamentals of marketing research in the field of tourism", Bulletin of the Berdyansk. University of Management and Business, vol. 3, pp. 52-56.

9. Pestushko, V. M. (2015)," Ukrainian tourism in the context of globalization: current state and prospects", Geography and basics of economics, vol. 7, pp. 257-265.

10. Organization Barometr", available at: http:/ / mkt.un wto.org/ barometer .

11. The official site of bttp://mkt.unwto.org/barometer United Nations World Tourism Organization (2018), "Statistics", available at: http:// www2.unwto.org/ .

12. The official site of http://mk.tunwto.org/barometer Eurostat (2018), "Dynamics of tourist flows", available at: bttp:/ / ec.europa.eu/ eurostat.

13.The official site of http://mkt.unwto.org/barometer Entrepreneurship (2018), available at: bttps:// www.usnews.com/ news/best-countries/ entrepreneurship-rankings.

14. The official site of http://mkt.unwto.org/barometerState Statistics Service of Ukraine (2018), available at: bttp:/ / wnw.ukrstat.gov.ual .

15. The official site of http:/ /mkt.unwto.org/barometer State Border Guard Service of Ukraine (2018), available at: https:/ / dpsu.gov.ual . 
International Conference "Risk in Contemporary Economy" ISSN-L 2067-0532 ISSN online 2344-5386

$X^{\text {th }}$ Edition, 2019, Galati, Romania,

"Dunarea de Jos" University of Galati, Romania - Faculty of Economics and Business Administration

16. The official site of http:/ / mkt.unwto.org/barometer the Main Department of Statistics in Kyiv (2018), available at: http:/ / wnw.kiev.ukrstat.gov.ual .

17. Rating of Ukrainian tour operators (2016), available at: http:/ / joinuplviv.com/ reitynh-turoperatoriv-ukrainy-2016/ .

18. The official site of http:/ / mkt.unwto.org/barometer Ukrainian marketing group. Available at: http:/ / wnw.umg.ua/ .

19. Rating of Ukrainian tour operators (2017), available at: http:/ / wmw.turproficom.ua/ rejtingi/2046-letnie-rejtingituroperatorov-po-turtsii-2017.

20.The official site of http://mkt.unwto.org/barometer State Administration of Kyiv (2018), available at: https:/ /kyivcity.gov.ual .

21. Lyashkevich, P. (2014), Turyzm v Ukraini: Suchasnyjstan ta priorytetyrozvytku [Tourism in Ukraine. Current situation and development priorities], Kyiv, Ukraine.

22. The official site of bttp://mkt.unwto.org/barometer Ministry of Finance of Ukraine (2018), available at: https:// minfin.gov.ua/. 